\title{
Hexabromocyclododecane Decreases the Lytic Function and ATP Levels of Human Natural Killer Cells
}

\author{
Natasha C. Hinkson ${ }^{1}$ and Margaret M. Whalen \\ Department of Biological Sciences, Tennessee State University, Nashville, TN 37209 \\ ${ }^{1}$ Department of Chemistry, Tennessee State University, Nashville, TN 37209
}

\begin{abstract}
This study investigates the effect of Hexabromocyclododecane (HBCD) on the lytic function of human natural killer (NK) cells and on ATP levels in NK cells. NK cells are capable of lysing tumor cells, virally infected cells, and antibody-coated cells. HBCD is a, brominated cyclic alkane used primarily as an additive flame retardant. If $\mathrm{HBCD}$ interferes with $\mathrm{NK}$ cell function, this could increase risk of tumor development and/or viral infection. NK cells were exposed to various concentrations of $\mathrm{HBCD}$ for $24 \mathrm{~h}, 48 \mathrm{~h}$, and 6 days before determining lytic function and ATP levels. ATP levels and lytic function were also determined in NK cells that were exposed to HBCD for $1 \mathrm{~h}$ followed by $24 \mathrm{~h}, 48 \mathrm{~h}$, and 6 days in HBCD-free media. The results indicated that exposure of NK cells to 10 $\mu \mathrm{M} \mathrm{HBCD}$ for $24 \mathrm{~h}$ causes a very significant decrease in both NK cell lytic function and ATP levels (93.5\% and 90.5\%, respectively). Exposure of NK cells to $10 \mu \mathrm{M} \mathrm{HBCD}$ for $1 \mathrm{~h}$ followed by $24 \mathrm{~h}$ in HBCD-free media showed a progressive and persistent loss of lytic function (89.3\%) as well as a decrease in ATP levels (46.1\%). The results indicate that HBCD exposures decreased lytic function as well as ATP levels. However, a decrease in lytic function was not necessarily accompanied by a similar decrease in ATP. Importantly, these results also indicate that a brief $(1 \mathrm{~h})$ exposure to HBCD causes a progressive loss of lytic function over a $6 \mathrm{~d}$ period.
\end{abstract}

\section{Keywords}

ATP; NK cells; Hexabromocyclododecane; lytic function

\section{INTRODUCTION}

Hexobromocyclododecanes (HBCDs) are non-aromatic, brominated cyclic alkanes used primarily as additive flame retardants (Birnbaun et al., 2004). HBCDs are used in foam and expanded polystyrene. End products include upholstered furniture, interior textiles, as well as building materials such as house walls, cellars, roofs and parking decks (de Wit, 2002). In 2001, 16,700 metric tons were produced worldwide, in which, 9500 metric tons were sold in the European Union.

Since HBCDs are not chemically bound to plastics or textiles, they can separate and leach from the surface of these products into the environment (de Wit, 2002). HBCDs are extremely hydrophobic/lipophilic compounds and thus have high potential for bioaccumulation (Germer et al., 2006). They have been detected in soil, sediment and sewage sludge (Hale et al., 2006), and also in dust particles in the air (Abdallah et al., 2008). HBCDs have also been found

Correspondence: Margaret M. Whalen, Department of Chemistry, Tennessee State University, 3500 John A. Merritt Blvd. Nashville, TN 37209, Email: mwhalen@ nnstate.edu, Phone: 615-963-5247, Fax: 615-963-5326. 
in several species of bird eggs (Bustnes et al., 2007; Polder et al.,2008), and marine animals (Peck et al., 2008), indicating accumulation/biomagnification in the food chain (Covaci et al., 2006). HBCDs are found in sewage sludge (de Boer et al., 2002; Sellstrom et al., 1999) and agricultural use of these sludges may distribute the HBCDs to the soil and thus into the food chain (Covaci et al. 2006). A Swedish study found elevated levels of HBCDs in air and sediments (Remberger et al., 2004). This same study also found atmospheric deposition of HBCDs at a remote site indicating that the persistence of HBCDs is such that they may undergo long-range transport (Remberger et al., 2004). HBCDs do not appear to be metabolized and in rainbow trout have been shown to decrease the cytochrome P4501A (CYP1A) protein levels and enzyme activity and to induce the enzyme, catalase (Ronisz et al., 2004).

Human exposure to HBCDs is believed to be through dust ingestion and dietary exposure (Abdallah et al., 2008) mainly through seafood (Knutsen et al., 2008; van Leeuwen et al., 2008). Moderate concentrations of HBCDs ( $100 \mathrm{pg} / \mathrm{g}$ of whole blood and $200 \mathrm{pg} / \mathrm{g}$ serum) have been found in human blood (Covaci et al., 2006; Knutsen et al., 2008), adipose tissue (Pulkrabova et al., 2009), and breast milk (Kakimoto et al., 2008; Thomsen et al., 2005; Thomsen et al., 2003). There are limited studies on the toxicological effects of HBCD on humans; however there have been studies on lab animals. van der Ven et al found when rats were exposed to HBCD, there was an increase in liver and pituitary weight, and also increased levels of cholesterol (van der Ven et al., 2006). HBCD has also been shown to have neurotoxic effects in mice (Eriksson et al., 2006) and to increase hepatic cytochrome P450 levels in rats (Germer et al., 2006).

Human Natural Killer (NK) cells are a subset of lymphocytes that are capable of killing tumor cells, virally infected cells, and antibody-coated cells. NK cells are defined by the absence of the $\mathrm{T}$ cell receptor/CD3 complex and by the presence of the CD56 and/or CD16 on the cell surface (Lotzova, 1993). NK cells play a central role in immune defense against viral infection and formation of primary tumors (Lotzova, 1993; Vivier et al., 2004). NK cells are responsible for limiting the spread of blood-borne metastases as well as limiting the development of primary tumors (Lotzova, 1993). NK cells also play a central role in immune defense against viral infection as evidenced by increased incidences of viral infection seen in individuals where the NK subset of lymphocytes is completely absent (Fleisher et al., 1982; Biron et al., 1989). These cells are the front line of immune response against tumor and virally infected cells due to their ability to lyse appropriate target cells without prior sensitization. Interference with NKcell function by any compound could increase the risk of viral infection and tumor formation.

The goal of the current study was to examine whether HBCD interferes with the lytic function of NK cells. Effects of both chronic and acute ( $1 \mathrm{~h}$ followed by up to $6 \mathrm{~d}$ in HBCD-free media) exposures were examined. A progressive and/or persistent negative effect of a brief HBCD exposure indicates a potentially greater risk from the compound. Finally, the effects of HBCD on ATP levels in NK cells were studied, as decreases in ATP could account for a loss of lytic function.

\section{MATERIALS AND METHODS}

\section{Isolation of NK cells}

Peripheral blood from healthy adult (male and female) volunteer donors was used for this study. Buffy coats (source leukocytes) obtained from the American Red Cross (Portland, OR) or Lifeblood Biological Services (Memphis, TN) were used to prepare NK cells. Highly purified NK cells were obtained using a rosetting procedure. Buffy coats were mixed with $0.8 \mathrm{~mL}$ of RosetteSep human NK cell enrichment antibody cocktail (StemCell Technologies, Vancouver, British Columbia, Canada) per $45 \mathrm{~mL}$ of buffy coat. The mixture was incubated for $25 \mathrm{~min}$ at room temperature $(\sim 25 \mathrm{o} C)$ with periodic mixing. Following the incubation, $7-8 \mathrm{~mL}$ of the 
mixture was layered onto $4 \mathrm{~mL}$ of Ficoll-Hypaque (1.077 g/mL) (MP Biomedicals, Irvine, CA) and centrifuged at $1200 \mathrm{~g}$ for $30 \mathrm{~min}$. The cell layer was collected and washed twice with phosphate buffered saline (PBS) $\mathrm{pH} 7.2$ and stored in complete media (RPMI-1640 supplemented with $10 \%$ heat-activated BCS, $2 \mathrm{mM} \mathrm{L}$-glutamine and $50 \mathrm{U}$ penicillin $\mathrm{G}$ with $50 \mu \mathrm{g}$ streptomycin $/ \mathrm{ml}$ ) at 1 million cells $/ \mathrm{mL}$. The resulting cell preparations used in the current study was $>95 \% \mathrm{CD} 16+$, and CD56+, $0 \% \mathrm{CD} 3+$ by fluorescence microscopy and flow cytometry (Whalen et al., 2002).

\section{Chemical preparation}

HBCD was purchased from Fisher Scientific. HBCD was dissolved in dimethylsulfoxide (DMSO) (Sigma-Aldrich, St. Louis, MO) to give a $100 \mathrm{mM}$ stock solution. Desired concentrations of HBCD were prepared by dilution of the stock into complete media containing $0.5 \%$ gelatin in place of the $10 \%$ bovine serum. Gelatin replaced BSA to avoid binding of HBCD to serum albumin, which could interfere with its delivery the cells. The final concentration of DMSO for HBCD exposures did not exceed $0.01 \%$.

\section{Cell Treatments}

NK cells (at a concentration of 1.5 million cells $/ \mathrm{mL}$ ) were exposed to $\mathrm{HBCD}$ or Control for $24 \mathrm{~h}, 48 \mathrm{~h}$ or 6 days. Following Exposures, the cells were assayed for tumor-destroying function or ATP levels. Additionally, NK cells were exposed to HBCD for $1 \mathrm{~h}$; following the $1 \mathrm{~h}$ exposure period, the HBCD-containing or control media was removed and replaced with fresh HBCD-free media and the cells were incubated in compound-free media for $24 \mathrm{~h}, 48 \mathrm{~h}$ or 6 days prior to being assayed for tumor-destroying function or ATP levels. The concentration range examined was $10 \mu \mathrm{M}-0.5 \mu \mathrm{M} \mathrm{HBCD}$.

\section{Cell Viability}

Cell viability was determined by trypan blue exclusion. Cell numbers and viability were assessed at the beginning and end of each exposure period. Viability was determined at each concentration for each of the exposure periods. The viability of treated cells was compared to that of control cells at each length of exposure (Whalen et al., 2003). Only those concentrations where viability was unaffected were used at a given length of exposure.

\section{Cytotoxicity assay}

The ability of NK cells to lyse tumor cells was measured using a ${ }^{51} \mathrm{Cr}$ release assay (Whalen et al., 1999). The target cell in all cytotoxicity assays was the NK-susceptible K562 (human chronic myelogenous leukemia) cell line. K562 cells were incubated with ${ }^{51} \mathrm{Cr}$ (Perkin-Elmer Life Sciences, Boston, MA) in 0.2- $0.5 \mathrm{ml}$ of BCS for $1-1.5 \mathrm{~h}$ at $37^{\circ} \mathrm{C}$ in air/CO $(19: 1)$. Following this incubation the target cells were washed twice with gelatin media. NK (effector) cells $\left(1.2 \times 10^{5} / 100 \mu \mathrm{L}\right.$ for $12: 1$ ratio with target cells) were added to the wells of round-bottom microwell plates. The effectors were diluted to $6: 1$ ratio $\left(0.6 \times 10^{5} / 100 \mu \mathrm{L}\right)$ and $3: 1$ ratio $\left(0.3 \times 10^{5} / 100 \mu \mathrm{L}\right)$; each ratio was tested in triplicate. Target cells were added $\left(1 \times 10^{4} / 100 \mu \mathrm{L}\right)$ to each well of the microwell plate and the plate was centrifuged at $300 \mathrm{~g}$ for $3.5 \mathrm{~min}$ and incubated for $2 \mathrm{~h}$ at $37{ }^{\circ} \mathrm{C}$ ( air/ $\left.\mathrm{CO}_{2}, 19: 1\right)$. After incubation a $0.1 \mathrm{ml}$ aliquot of the supernatant was collected and counted for radioactivity for $60 \mathrm{sec}$ in a Packard COBRA gamma radiation counter (Packard Instrument Co., Meriden, CT). Target lysis was calculated as follows: 100× [(test c.p.m - spontaneous c.p.m.)/maximum c.p.m.- spontaneous c.p.m.)]. Maximum release was produced by adding $100 \mu \mathrm{L}$ of $10 \%$ Triton X-100.

\section{ATP Assay}

Following exposures of cells to the various concentrations of HBCD; 250,000 NK cells were added to $300 \mu \mathrm{L}$ of somatic cell ATP releasing reagent (Sigma-Aldrich). To measure ATP, 
$100 \mu \mathrm{L}$ of the lysed cell suspension was added to $100 \mu \mathrm{L}$ of a Luciferin/Luciferase mixture (Sigma-Aldrich). The light emission was measured using a Fluoroskan Ascent FL luminescence plate reader (Thermo Electron Corp., Vantaa, Finland). ATP levels were determined from a standard curve (Dudimah et al., 2007).

\section{Statistical Analysis}

Statistical analysis of the data was carried out utilizing ANOVA and Student's $t$ test. Data were initially compared within a given experimental setup by ANOVA. A significant ANOVA was followed by pair wise analysis of control versus exposed data using Student's $t$ test.

\section{RESULTS \\ Effects of exposures to HBCD for $24 \mathrm{~h}, 48 \mathrm{~h}$, and 6 days on the Tumor-lysing function of NK Cells}

Highly purified NK cells were exposed to $2.5-10 \mu \mathrm{M} \mathrm{HBCD}$ for $1 \mathrm{~h}, 0.5-10 \mu \mathrm{M} \mathrm{HBCD}$ for $24 \mathrm{~h}, 0.25-2.5 \mu \mathrm{M}$ HBCD for $48 \mathrm{~h}$, and $0.25-1 \mu \mathrm{M}$ HBCD for 6 days. Exposure of NK cells to $10 \mu \mathrm{M}$ for $1 \mathrm{~h}$ caused a very small but statistically significant decreases in lytic function $(11.8 \% \pm 7 \%, \mathrm{p}<0.01)$. Exposures of NK cells to $2.5,5$ and $10 \mu \mathrm{M} \mathrm{HBCD}$ for $24 \mathrm{~h}$ caused very significant reductions in NK cell lytic function of $44.2 \pm 9.3 \%, 92.2 \pm 2.2 \%$, and $94.9 \pm 2.7 \%$, and respectively $(\mathrm{P}<0.0001)$ (Figure 1). There was no decrease of lytic function at $1 \mu \mathrm{M}$ and 0.5 $\mu \mathrm{M}$ concentrations with a $24 \mathrm{~h}$ exposure. NK cells were exposed to concentrations of $0.5-2.5$ $\mu \mathrm{M} \mathrm{HBCD}$ for $48 \mathrm{~h}$ because higher concentrations caused decreased viability of the NK cells. Exposure of NK cells to $2.5 \mu \mathrm{M}$ HBCD for $48 \mathrm{~h}$ decreased lytic function by $75.6 \pm 3.6 \%$ $(\mathrm{P}<0.0001)$ (Figure 1). Six day exposures of NK cells to HBCD were carried out at concentrations of $0.25 \mu \mathrm{M}-1 \mu \mathrm{M}$, as higher concentrations of HBCD decreased the viability of the NK cells. There was a decrease in tumor-lysing function with a $6 \mathrm{~d}$ exposure to $1 \mu \mathrm{M}$ $\mathrm{HBCD}$ of $44 \pm 26.6 \%(\mathrm{P}<0.02)$ (Figure 1$)$.

\section{Effects of Exposures to HBCD for $1 \mathrm{~h}$ Followed by $24 \mathrm{~h}, \mathbf{4 8} \mathrm{h}$, and 6 Days in HBCD-Free Media on the Tumor-Lysing Function of NK Cells}

NK cells were exposed to $10 \mu \mathrm{M}$ HBCD for 1 h showed only a $12 \%$ decrease in lytic function and those exposed to 5 or $2.5 \mu \mathrm{M} \mathrm{HBCD}$ showed no loss of lytic function (Figure 1). However, it is possible that an initial exposure to HBCD for $1 \mathrm{~h}$ could cause changes in NK cell lytic function that would manifest (and/or intensify) at later time points. To address this possibility, NK cells were exposed to $2.5-10 \mu \mathrm{M} \mathrm{HBCD}$ for $1 \mathrm{~h}$ which was then removed and the NK cells were then suspended in HBCD-free media for $24 \mathrm{~h}, 48 \mathrm{~h}$ or 6 days before assaying for lytic function. When NK cells were exposed to $2.5-10 \mu \mathrm{M}, \mathrm{HBCD}$ for $1 \mathrm{~h}$ and then incubated in HBCD-free media for $24 \mathrm{~h}$ prior to assaying for lytic function, decrease in lytic function of $24.9 \pm 13.5 \%(2.5 \mu \mathrm{M}), 69.2 \pm 28.4 \%(5 \mu \mathrm{M})$, and $89.3 \pm 10.6 \%(10 \mu \mathrm{M})$ were seen $(\mathrm{P}<0.0001)$ (Figure 2). NK cells exposed to these same concentrations of HBCD and incubated for $48 \mathrm{~h}$ in HBCD-free media prior to assay, showed reductions in lytic function of $22.1 \pm 20.7 \%(2.5 \mu \mathrm{M})$, $52.4 \pm 16.9 \%(5 \mu \mathrm{M})$, and $88.1 \pm 11.2 \%(10 \mu \mathrm{M})(\mathrm{P}<0.02)$. Exposure of NK cells to these same $\mathrm{HBCD}$ concentrations for $1 \mathrm{~h}$, followed by a 6 day period in HBCD-free media decreased lytic function $39.7 \pm 32.2 \%(2.5 \mu \mathrm{M}), 94.8 \pm 4.9 \%(5 \mu \mathrm{M})$, and $89.9 \pm 2.15 \%(10 \mu \mathrm{M}),(\mathrm{P}<0.0001)$.

\section{Effects of Exposures to HBCD for 24 h, 48 h, and 6 Days on ATP Levels in NK Cells}

To determine the effects of varying concentrations of HBCD on the ATP levels in human NK cells, the cells were exposed to HBCD or control for the indicated lengths of time and the amount of ATP in control cells and treated cells were calculated from a standard curve. To combine results from separate experiments (using cells from different donors) the levels of ATP were normalized to the ATP level from the control cells in a given experiment (percentage 
of control). NK cells exposed to $2.5 \mu \mathrm{M}, 5 \mu \mathrm{M}$, and $10 \mu \mathrm{M}$ HBCD for 24 h showed significant decreases in ATP levels of $52.4 \pm 15.9 \%, 78.4 \pm 2.8 \%$, and $90.5 \pm 3.1 \%$, respectively $(\mathrm{P}<0.0001)$ (Figure 3). A reduction in ATP levels of $50.2 \pm 34.3 \%$ was seen with a $48 \mathrm{~h}$ exposure to 2.5 $\mu \mathrm{M}$ HBCD $(\mathrm{P}<0.0001)$ (Figure 3 ). A 6 day exposure of NK cells to $0.5 \mu \mathrm{M}$ and $1 \mu \mathrm{M}$ HBCD lead to very small decreases in ATP levels of $26.7 \pm 32.2 \%$ and $13.8 \pm 19.0 \%$, respectively $(\mathrm{P}<0.02)$ (Figure 3).

\section{Effects of Exposures to HBCD for $1 \mathrm{~h}$ Followed by, $24 \mathrm{~h}, \mathbf{4 8} \mathrm{h}$, and 6 Days in HBCD-Free Media on ATP Levels in NK Cells}

As with lytic function, it is possible that an initial exposure to HBCD for $1 \mathrm{~h}$ could cause changes in NK cell ATP levels that would manifest later, even thought the compound has been removed. Thus, we examined if the effects of exposures to HBCD persisted and/or intensified following removal of the compound. To address this possibility, NK cells were exposed to 2.5 $-10 \mu \mathrm{M}$ HBCD for $1 \mathrm{~h}$ which was then removed and the NK cells were then suspended in HBCD-free media for $24 \mathrm{~h}, 48 \mathrm{~h}$ or 6 days before assaying for ATP levels. NK cells exposed to HBCD for $1 \mathrm{~h}$ and then incubated for $24 \mathrm{~h}$ in HBCD-free media prior to measuring ATP levels showed decreases of $23.2 \pm 10.8 \%(2.5 \mu \mathrm{M}), 39 \pm 15 \%(5 \mu \mathrm{M})$, and $46.2 \pm 30.1 \%(10 \mu \mathrm{M})$, $(\mathrm{P}<0.001)$ (Figure 4). NK cells were exposed to 5 and $10 \mu \mathrm{M} \mathrm{HBCD}$ for $1 \mathrm{~h}$ and given a $48 \mathrm{~h}$ period in HBCD-free media before assay showed decreases in ATP levels of $37.5 \pm 52.1 \%$ and $55.1 \pm 46.8 \%$, respectively $(\mathrm{P}<0.05)$ (Figure 4$)$. A $1 \mathrm{~h}$ exposure of NK cells to $2.5 \mu \mathrm{M} \mathrm{HBCD}$ followed by $6 \mathrm{~d}$ in HBCD-free media lead to a decrease in ATP of 50.3 $\pm 39.6 \%(\mathrm{P}<0.01)$ (Figure 4).

\section{DISCUSSION}

The ability of NK cells to lyse tumor cells is an essential immune function that if compromised could leave an individual with an increased susceptibility to developing cancer (Lotzova, 1993). HBCD has been found in bird eggs (Bustnes et al., 2007; Polder et al.,2008), and marine animals (Peck et al., 2008), indicating that it is accumulating and biomagnifiying in the food chain (Covaci et al., 2006). HBCD is found in sewage sludge (de Boer et al., 2002; Sellstrom et al., 1999) and agricultural use of these sludges may distribute the HBCDs to the soil and thus into the food chain (Covaci et al. 2006). It appears that there may be emission of HBCD from the products in which it is used and that it may undergo long-range transport (Remberger et al., 2004). HBCD does not appear to be metabolized (Ronisz et al., 2004). As HBCD is a very prevalent environmental contaminant that is found in human tissues (Covaci et al., 2006; Kakimoto et al., 2008; Knutsen et al., 2008; Pulkrabova et al., 2008; Thomsen et al., 2005; Thomsen et al., 2003) and does not appear to be metabolized ((Ronisz et al., 2004), it is important to examine its capacity to interefere with human NK cell function. This study examined whether HBCD exposure decreases the lytic function of NK cells. Additionally, this study examined if the effects of exposures to HBCD persisted and/or intensified following removal of the compound. If $\mathrm{HBCD}$ is able to cause continued disruption of NK function even after its removal this has implications for the level of hazard that even a limited exposure could present. Finally, in order to begin to address the mechanism of HBCD-induced decreases in lytic function, the effects of HBCD on ATP levels in NK cells were also examined, as the process by which NK cells lyse tumor cells is ATP-dependent (Andzelm et al., 2007).

Exposure of NK cells to $10 \mu \mathrm{M}$ HBCD for $24 \mathrm{~h}$ caused a very significant decrease in the ability of NK cells to lyse tumors cells, and also caused very significant decreases in levels of ATP. The decreases in ATP levels were roughly comparable to those of lytic function for each of the concentrations tested at $24 \mathrm{~h}$. These results suggested that HBCD-induced decreases in ATP may in part cause the decreases in the lytic function seen after a 24 hour exposure to HBCD (Figure 5A). After a $48 \mathrm{~h}$ exposure to HBCD the decrease in ATP levels was about 
$76 \%$ and the decrease in ATP was about 50\% with exposure to $2.5 \mu \mathrm{M} \mathrm{HBCD}$ (Figure 5B). A 6 day exposure of NK cells to $2.5 \mu \mathrm{M} \mathrm{HBCD}$ decreased lytic function by greater than $90 \%$ and decreased ATP levels by about 47\% (Figure 5C). The decreases in ATP levels seen with 2.5 $\mu \mathrm{M}$ HBCD after $48 \mathrm{~h}$ and $6 \mathrm{~d}$ of exposure were both about $50 \%$. This may suggest that a decrease in ATP of 50\% is sufficient to decrease lytic function, which as mentioned above is an ATP-dependent process (Andzelm et al., 2007). However, exposure to $1 \mu \mathrm{M}$ HBCD for 6 $\mathrm{d}$ caused a $44 \%$ decrease in lytic function but decreased ATP levels by only $13 \%$. Previous studies using rotenone and oligomycin have shown that 13\% decrease in ATP is not sufficient to cause any decrease in NK lytic function (Dudimah et al., 2007). Thus, the loss of lytic function seen with this exposure cannot be explained by ATP decreases.

As mentioned above, if loss of lytic function seen with HBCD exposures were to persist and/ or intensify after the removal of the compound, this would indicate a potentially greater danger due to even a brief exposure to low levels of HBCD. The levels reported to be found in human serum average near $0.3 \mathrm{nM}$ (Covaci et al., 2006). The results of studies examining the effects of a $1 \mathrm{~h}$ exposure followed by $24 \mathrm{~h}, 48 \mathrm{~h}$, and $6 \mathrm{~d}$ in HBCD-free media on tumor lysing function were similar to those seen when NK cells were continuously exposed to HBCD for $24 \mathrm{~h}, 48 \mathrm{~h}$, or 6 days. A $1 \mathrm{~h}$ exposure to $10 \mu \mathrm{M} \mathrm{HBCD}$ caused almost no decreases in lytic function (11.8\%). However, in the $24 \mathrm{~h}$ period following this $1 \mathrm{~h}$ exposure the loss of lytic function was dramatically increased to about $90 \%$. Importantly, the results show that a concentration such as $5 \mu \mathrm{M} \mathrm{HBCD}$ (which has no effect on NK lytic function after a $1 \mathrm{~h}$ exposure) causes a $70 \%$ loss of lytic function within the $24 \mathrm{~h}$ period following that exposure. This loss escalates to greater than $90 \%$ by $6 \mathrm{~d}$ following the initial $1 \mathrm{~h}$ exposure. Thus, there is a progressive impairment of NK cell function following a brief initial exposure to HBCD. In the periods following $1 \mathrm{~h}$ exposures to HBCD there were also decreases in ATP levels, which may possibly account for some of the loss of lytic function.

These results suggest that HBCD induces processes that lead to the persistent inhibition of the lytic process. Irreversible inhibitory binding of HBCD to a component(s) of the NK cell that is(are) needed for lytic function, may be one possible explanation. HBCD is a very lipophilic compound (Germer et al., 2006) and thus it may to some extent associate with cell membranes and thus alter the function of membrane proteins needed for binding and or recognition of target cells by NK cells. There are many possible target proteins in the NK cell where a hydrophobic compound such as HBCD might bind. The active sites of most cellular enzymes are usually hydrophobic pockets created from the protein structure (Copeland and Anderson, 2002) and would thus be ideal locations for HBCD to bind depending on whether the overall shape of the active site could accommodate the size of the HBCD. Enzymes critical to the NK lytic process, such as the mitogen activated protein kinase (MAPK) pathway (Trotta et al, 1998; Trotta et al., 2000; Wei et al., 1998) or the myosin IIA (Andzelm et al., 2007) needed for release of cytotoxic granules are just a few of the many possible targets. Previously we have shown that the activity of MAPK pathway enzymes was altered by another hydrophobic environmental contaminant, tributyltin (TBT), when NK cells were exposed for as little as 10 minutes (Aluoch and Whalen, 2005, Aluoch et al., 2006, Aluoch et al., 2007). Additionally, HBCD may bind in mitochondrial membranes either by associating in the lipid portion or by binding to specific proteins and this may lead to interference with electron transport/oxidative phosphorylation and decreased ATP levels. Again, TBT has been shown to bind to the Fo portion of F-ATP synthase in bacteria, which is very similar to mitochondrial ATP synthase (von Ballmoos et al., 2004). Further studies are needed to examine these potential areas of HBCD interaction with NK cells. However, it is clear from the current study that HBCD interferes with the ability of NK cells to carry out their essential function of lysing tumor cells. Thus, it has the potential for increasing the risk of cancer development in exposed individuals. 


\section{Acknowledgments}

This research was supported by Grant 2S06GM-08092-34 from the National Institutes of Health.

\section{References}

Abdallah Mohamed AE, Harrad S, Ibarra C, Diamond M, Melymuk L, Robson M, Covaci A. Hexabromocyclododecanes in indoor dust from Canada, the United Kingdom, and the United States. Environmental science \& technology 2008;42:459-464. [PubMed: 18284147]

Aluoch AO, Whalen MM. Tributyltin-induced effects on MAP kinases p38 and p44/42 in human natural killer cells. Toxicology 2005;209:263-277. [PubMed: 15795062]

Aluoch AO, Odman-Ghazi SO, Whalen MM. Alteration of an essential NK cell signaling pathway by low doses of tributyltin in human natural killer cells. Toxicology 2006;224:229-237. [PubMed: 16781040]

Aluoch AO, Odman-Ghazi SO, Whalen MM. Pattern of MAP kinases p44/42 and JNK activation by nonlethal doses of tributyltin in human natural killer cells. Arch Toxicol 2007;81:271-277. [PubMed: 17019560]

Andzelm MM, Chen X, Krzewski K, Orange JS, Strominger JL. Myosin IIA is required for cytolytic granule exocytosis in human NK cells. J Exp Med 2007;204:2285-2291. [PubMed: 17875677]

Birnbaum LS, Staskal DF. Brominated flame retardants: cause for concern? Environmental Health Perspectives 2004;112:9-1. [PubMed: 14698924]

Biron CA, Byron KS, Sullivan JL. Severe herpes virus in an adolescent without natural killer cells. New Engl J Med 1989;320:1731-1735. [PubMed: 2543925]

Bustnes JO, Yoccoz NG, Bangjord G, Polder A, Skaare JU. Temporal trends (1986-2004) of organochlorines and brominated flame retardants in tawny owl eggs from northern Europe. Environmental Science and Technology 2007;41:8491-8497. [PubMed: 18200884]

Copeland, RA.; Anderson, PS. Enzymes and enzyme inhibitors. In: Madsen, U.; Liljefors, T., editors. Textbook of drug design and discovery. Vol. 3. CRC press; 2002.

Covaci A, Gerecke AC, Law RJ, Voorspoels S, Kohler M, Heeb NV, Leslie H, Allchin CR, De Boer J. Hexabromocyclododecanes (HBCDs) in the environment and humans: A review. Environmental Science and Technology 2006;40:3679-3688. [PubMed: 16830527]

de Boer, J.; Allchin, C.; Zegers, B.; Boon, JP.; Brandsma, SH.; Morris, S.; Kruijt, AW.; van der Hesselingen, JM.; Haftka, JJ. HBCD and TBBP-A in sewage sludge, sediments and biota, including interlaboratory study; CO33/02;. RIVO-Netherlands Institute for Fisheries Research; Wageningen, The Netherlands: 2002. p. p40

de Wit CA. An overview of brominated flame retardants in the environment. Chemosphere 2002;46:583624. [PubMed: 11999784]

Dudimah FD, Odman-Ghazi SO, Hatcher F, Whalen MM. Effect of tributyltin (TBT) on ATP levels in human natural killer (NK) cells: relationship to TBT-induced decreases in NK function. J Appl Toxicol 2007;27:86-94. [PubMed: 17149696]

Eriksson P, Fischer C, Wallin M, Jakobsson E, Frederisson A. Impaired behaviour, Learning and memory, in adult mice neonatally exposed to hexabromocyclododecane (HBCDD). Environ Toxicol Pharmacol 2006;21:317-322.

Fleisher G, Koven N, Kamiya H, Henle W. A non-X-linked syndrome with susceptibility to severe Epstein-Bar virus infections. J Pediatr 1982;100:727-730. [PubMed: 6279813]

Germer S, Piersma AH, van der Ven L, Kamyschnikow A, Fery Y, Schmitz H-J, Schrenk D. Subacute effects of the brominated flame retardants hexabromocyclododecane and tetrabrombisphenol A on hepatic cytochrome P450 levels in rats. Toxicology 2006;218:229-236. [PubMed: 16325980]

Hale RC, La Guardia MJ, Harvey E, Gaylor MO, Mainor TM. Brominated flame retardant concentrations and trends in abiotic media. Chemosphere 2006;64:181-186. [PubMed: 16434082]

Kakimoto K, Akutsu K, Konishi Y, Tanaka Y. Time trend of hexabromocyclododecane in the breast milk of Japanese women. Chemosphere 2008;71:1110-1114. [PubMed: 18076970]

Knutsen HK, Kvalem HE, Thomsen C, Froshaug M, Haugen M, Becher G, Alexander J, Meltzer HM. Dietary exposure to brominated flame retardants correlates with male blood levels in a selected group 
of Norwegians with a wide range of seafood consumption. Molecular nutrition $\&$ food research 2008;52:217-227. [PubMed: 18246586]

Lotzova E. Definition and function of natural killer cells. Nat Immun 1993;12:177-193. [PubMed: 8257825]

Peck AM, Pugh RS, Moors A, Ellisor MB, Porter BJ, Becker PR, Kucklick JR. Hexabromocyclododecane in white-sided dolphins: temporal trend and stereoisomer distribution in tissues. Environmental Science \& Technology 2008;42:2650-2655. [PubMed: 18505011]

Polder A, Venter B, Skaare JU, Bouwman H. Polybrominated diphenyl ethers and HBCD in bird eggs of South Africa. Chemosphere 2008;73:148-154. [PubMed: 18466951]

Pulkrabova J, Hradkova P, Hajslova J, Poustka J, Napravnikova M, Polacek V. Brominated flame retardants and other organochlorine pollutants in human adipose tissue samples from the Czech Republic. Environment International 2009;35:63-68. [PubMed: 18789823]

Remberger M, Sternbeck J, Palm A, Kaj L, Stromberg K, Brorstrom-Lunden E. The environmental occurrence of hexabromocyclododecane in Sweden. Chemosphere 2004;54:9-21. [PubMed: 14559253]

Ronisz D, Farmen Finne E, Karlsson H, Forlin L. Effects of the brominated flame retardants hexabromocyclododecane(HBCDD), and tetrabromobisphenol A (TBBPA), on hepatic enzymes and other biomarkers in juvenile rainbow trout and feral eelpout. Aquatic Toxicology 2004;69:229-245. [PubMed: 15276329]

Sellstrom U, Kierkegaard A, Alsberg T, Jonsson P, Wahlberg C, deWit C. Brominated flame retardants in sediments from European estuaries, the Baltic Sea and in sewage sludge. Organohalogen Compd 1999;40:383-386.

Thomsen C, Froshaug M, Leknes H, Becher G. Brominated flame retardants in breast milk from Norway. Organohalogen Compd 2003;64:33-36.

Thomsen C, Froshaug M, Broadwell SI, Becher G, Eggesbo M. Levels of brominated flame retardants in milk from the Norwegian human milk study: HUMIS. Organohalogen Compd 2005;67:509-512.

Trotta R, Puorro KA, Paroli M, Azzoni L, Abebe B, Eisenlohr LC, Perussia B. Dependence of both spontaneous and antibody-dependent, granule exocytosis-mediated NK cell cytotoxicity on extracellular signal-regulated kinases. J Immunol 1998;161:6648-6656. [PubMed: 9862693]

Trotta R, Fettuciari K, Azzoni L, Abebe B, Puorro KA, Eisenlohr LC, Perussia B. Differential role of p38 and c-Jun N-terminal kinase 1 mitogen- activated protein kinases in NK cell cytotoxicity. J Immunol 2000;165:1782-1789. [PubMed: 10925255]

van der Ven LT, Verhoef A, van de Kuil T, Slob W, Leonards PE, Visser TJ, Hamers T, Herlin M, Hakansson H, Olausson H, Piersma AH, Vos JG. A 28-day oral dose toxicity study enhanced to detect endocrine effects of hexabromocyclododecane in Wistar rats. Toxicol Sci 2006;94:281-92. [PubMed: 16984958]

van Leeuwen SP, de Boer J. Brominated flame retardants in fish and shellfish -levels and contribution of fish consumption to dietary exposure of Dutch citizens to HBCD. Molecular Nutrition \& Food Research 2008;52:194-203. [PubMed: 18246585]

Vivier E, Nunes JA, Vely F. Natural killer cell signaling pathways. Science 2004;306:1517-1519. [PubMed: 15567854]

von Ballmoos C, Brunner J, Dimroth P. The ion channel of F-ATP synthase is the target of toxic organotin compounds. Proc Natl Acad Sci 2004;101:11239-11244. [PubMed: 15277681]

Wei S, Gamero AM, Liu JH, Daulton AA, Valkov NI, Trapani JA, Larner AC, Weber MJ, Djeu JY. Control of lytic function by mitogen-activated protein kinase/extracellular regulatory kinase 2 (ERK2) in a human natural killer cell line: identification of perforin and granzyme B mobilization by functional ERK2. J Exp Med 1998;187:1753-1765. [PubMed: 9607917]

Whalen MM, Loganathan BG, Kannan K. Immunotoxicity of environmentally relevant concentrations of butyltins on human natural killer cells in vitro. Environ Res 1999;81:108-116. [PubMed: 10433842]

Whalen MM, Green SA, Loganathan BG. Brief butyltin exposure induces irreversible inhibition of the cytotoxic function on human natural killer cells, in vitro. Environ Res 2002;88:19-29. [PubMed: 11896664] 
Whalen MM, Loganathan BG, Yamashita N, Saito T. Immunomodulation of human natural killer cell cytotoxic function by triazine and carbamate pesticides. Chemico-Biological Int 2003;145:311-319. 


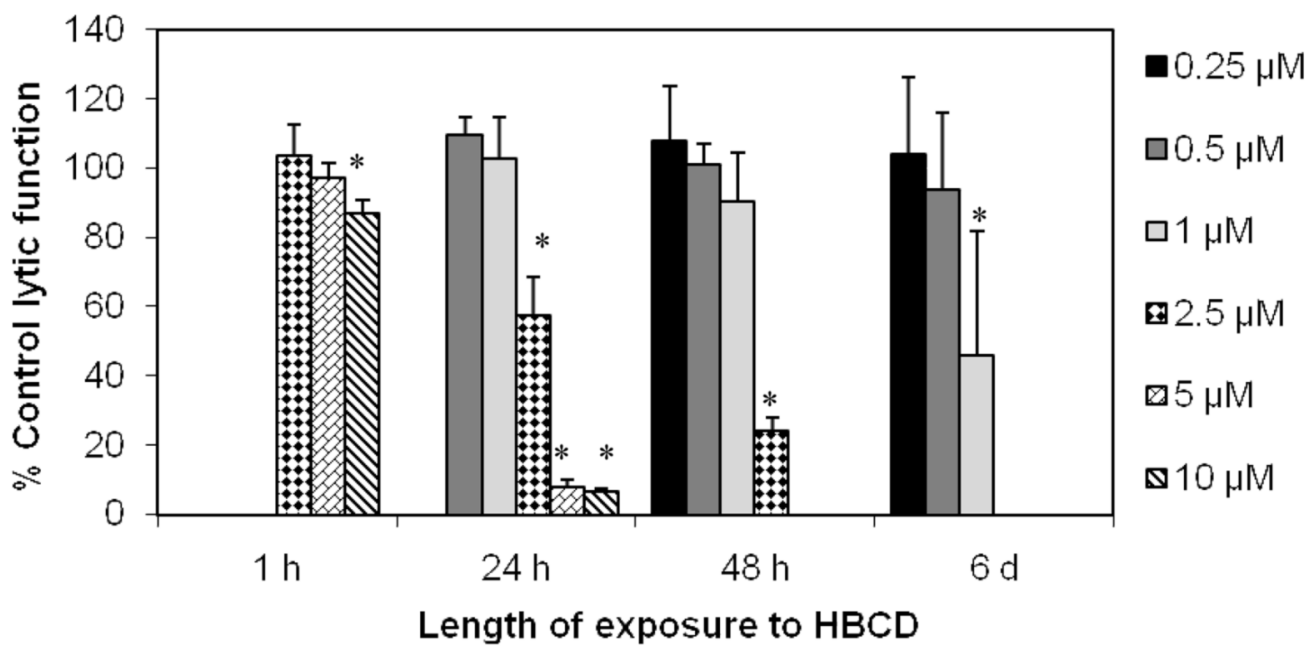

Figure 1.

Effects of HBCD exposures on the ability of NK cells to lyse tumor cells. NK cells were exposed to $10-0.25 \mu \mathrm{M}$ HBCD for $1 \mathrm{~h}, 24 \mathrm{~h}, 48 \mathrm{~h}$, or 6 days. To combine results from separate experiments (using cells from different donors) the levels of lysis were normalized as the percentage of the lytic function of the control cells in a given experiment. Results were from three separate experiments using different donors (triplicate determinations for each experiment, $n=9$, mean \pm S.D.). * indicates statistically significant change $(p<0.05)$ 


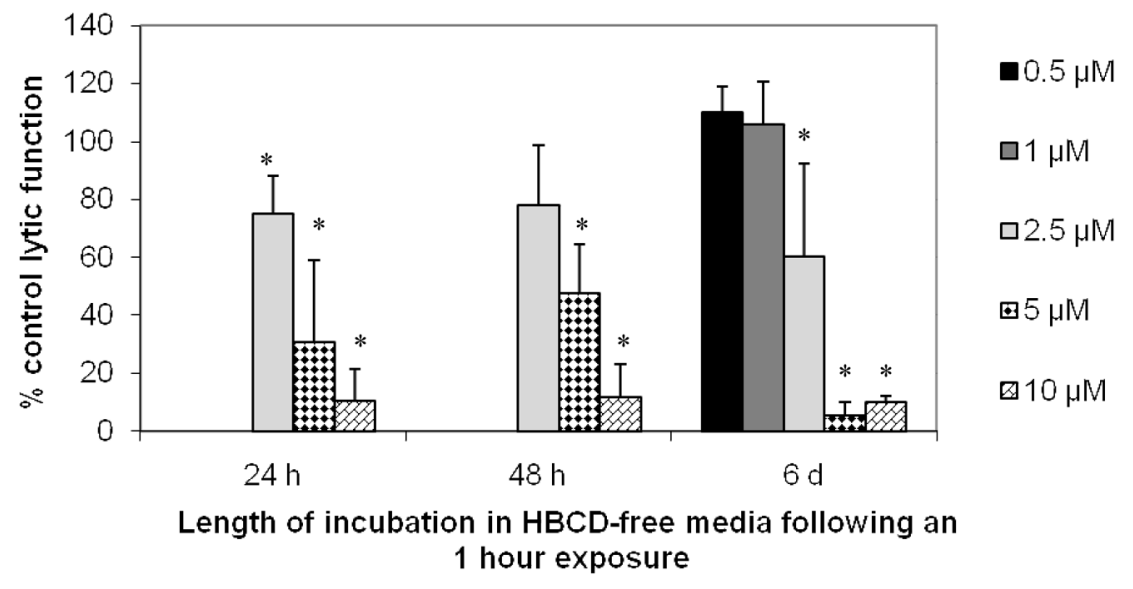

Figure 2.

Effects of $1 \mathrm{~h}$ exposures to HBCD followed by $24 \mathrm{~h}, 48 \mathrm{~h}$, or 6 days in HBCD-free media on the ability of NK cells to lyse tumor cells. NK cells were exposed to $10-0.5 \mu \mathrm{M}$ HBCD for 1 h. Results were from at least three separate experiments using different donors (triplicate determinations for each experiment, $n=9$, mean \pm S.D.), as described in Figure 1. * indicates statistically significant change $(\mathrm{p}<0.05)$ 


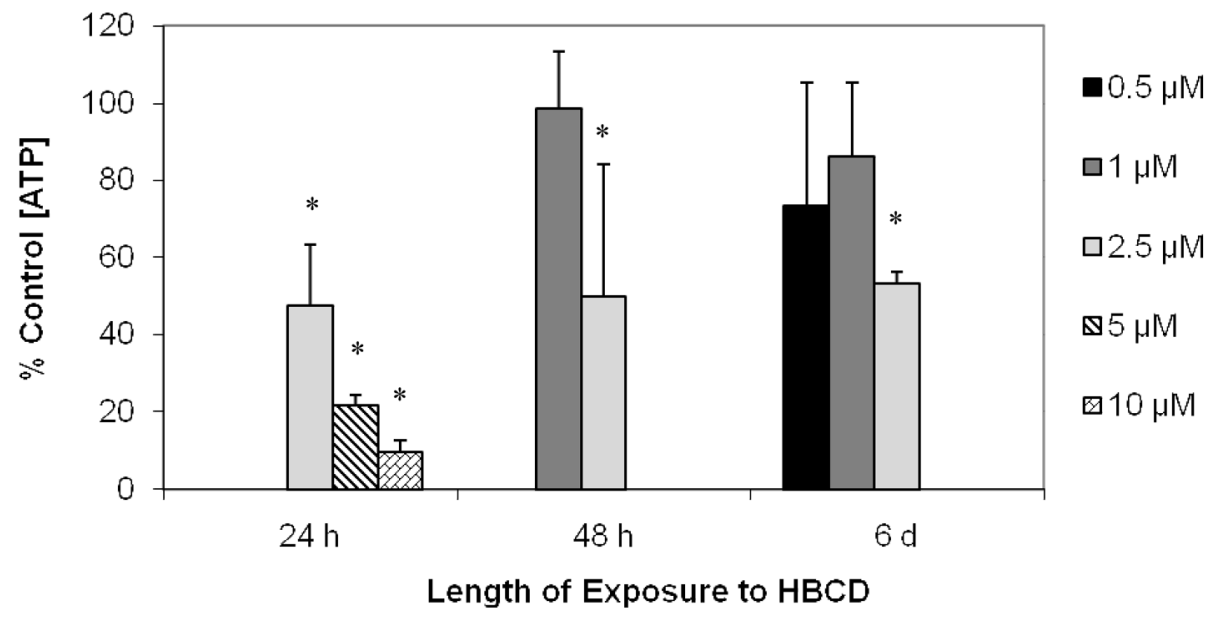

Figure 3.

Effects of HBCD exposures on ATP levels NK cells. NK cells were exposed to 10-0.5 $\mu \mathrm{M}$ HBCD for $24 \mathrm{~h}, 48 \mathrm{~h}$, or 6 days. To combine results from separate experiments (using cells from different donors) the levels of ATP were normalized as the percentage of the ATP level from the control cells in a given experiment. Results were from three separate experiments using different donors (triplicate determinations for each experiment, $\mathrm{n}=9$, mean \pm S.D.). * indicates statistically significant change $(\mathrm{p}<0.05)$ 


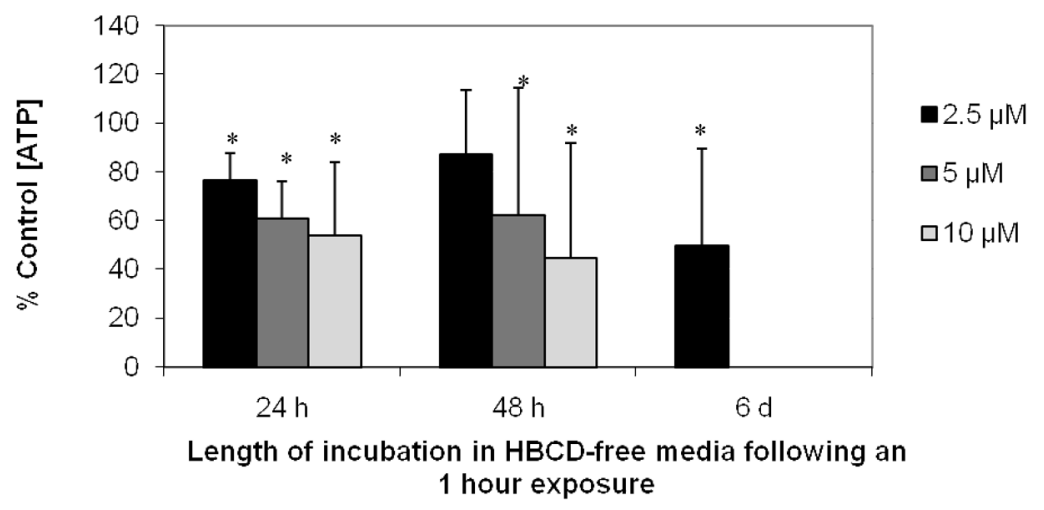

Figure 4.

Effects of $1 \mathrm{~h}$ exposures to HBCD followed by $24 \mathrm{~h}, 48 \mathrm{~h}$, or 6 days in HBCD-free media on the ATP levels in NK cells. NK cells were exposed to 10-2.5 $\mu \mathrm{M}$ HBCD for $1 \mathrm{~h}$. Results were from at least three separate experiments using different donors (triplicate determinations for each experiment, $n=9$, mean \pm S.D.), as described in Figure 3. * indicates statistically significant change $(\mathrm{p}<0.05)$ 
A

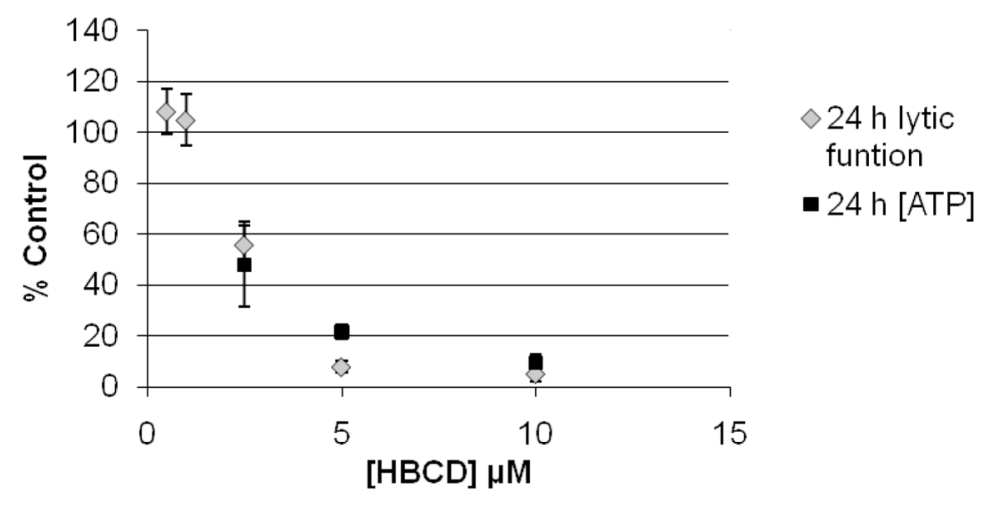

B

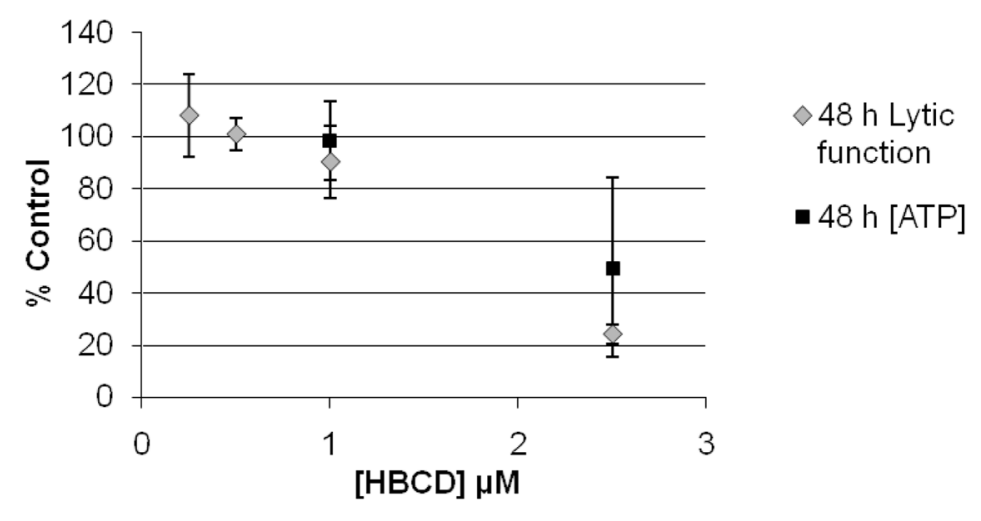


C

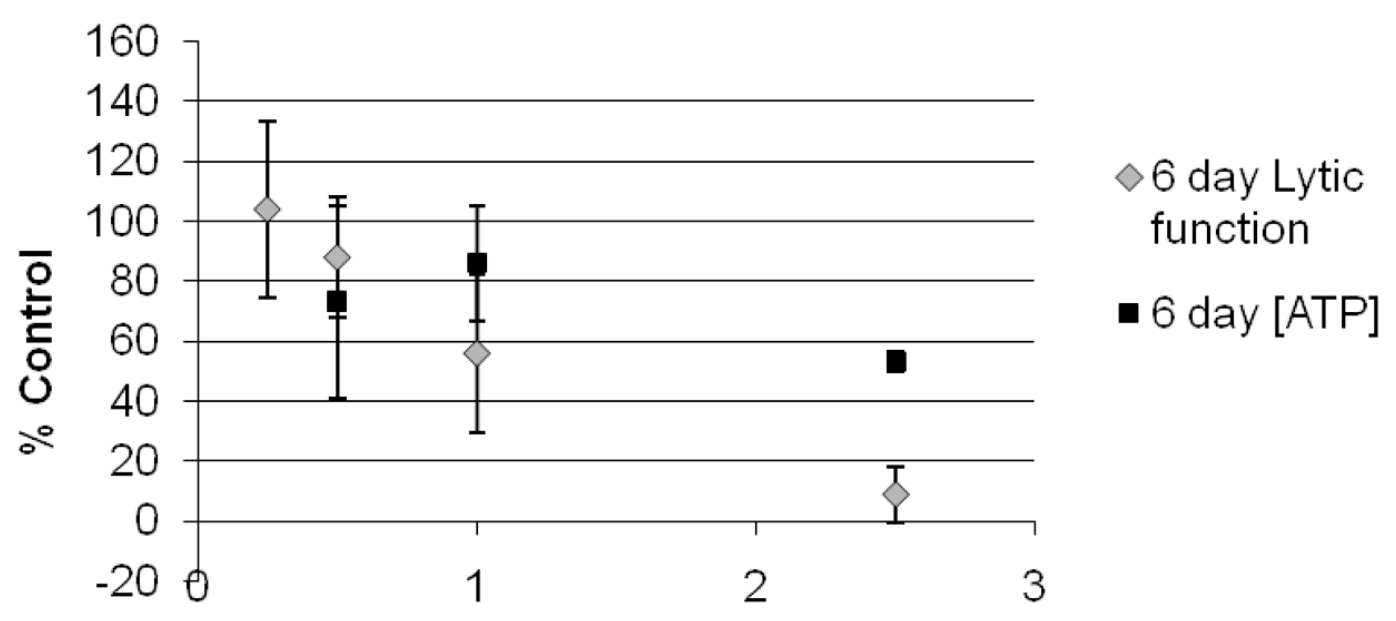

[HBCD] $\mu \mathrm{M}$

Figure 5.

Effects of HBCD exposure on lytic function and ATP levels (plotted on the same graph). (A) $1 \mathrm{~h}$ exposure to HBCD, (B) $24 \mathrm{~h}$ exposure to HBCD, (C) $48 \mathrm{~h}$ exposure to HBCD, (D) 6 days exposure to $\mathrm{HBCD}$. 
A

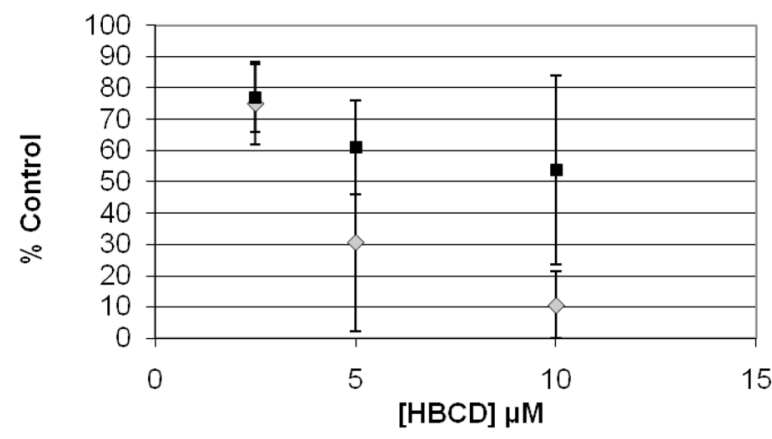

$\diamond 1 \mathrm{~h} / 24 \mathrm{~h}$ Lytic

Function

- $1 \mathrm{~h} / 24 \mathrm{~h}[$ ATP]

B

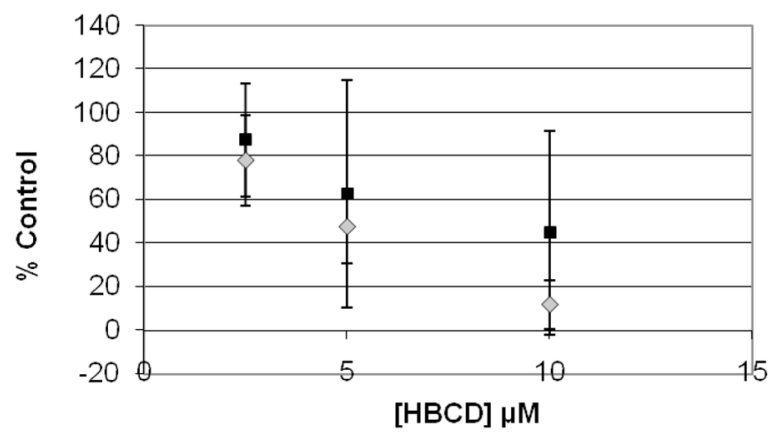

$\diamond 1 \mathrm{~h} / 48 \mathrm{~h}$ Lytic

Function

- $1 \mathrm{~h} / 48 \mathrm{~h}[\mathrm{ATP}]$

C

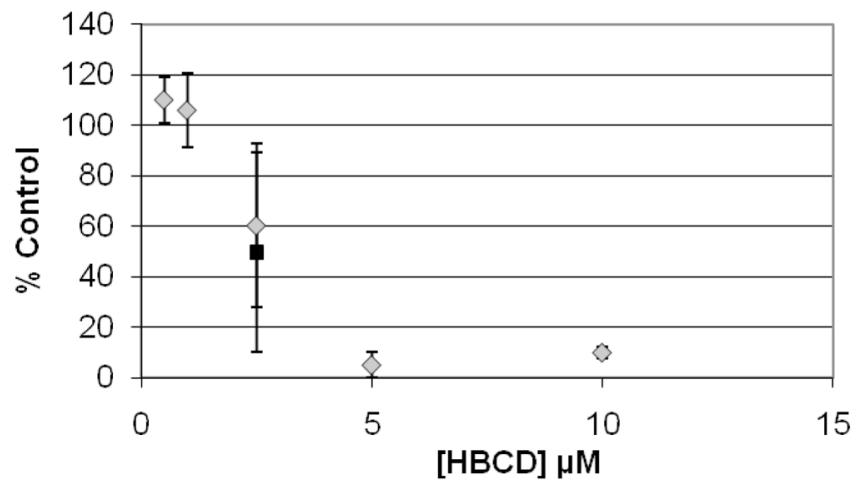

$\diamond 1 \mathrm{~h} / 6$ day Lytic

Function

- $1 \mathrm{~h} / 6$ day $[$ ATP]

Figure 6.

Effects of $1 \mathrm{~h}$ exposures to HBCD followed by varying periods in HBCD-free media on lytic function and ATP levels (plotted on the same graph). (A) 1 h exposure to HBCD followed by $24 \mathrm{~h}$ in HBCD-free media, (B) $1 \mathrm{~h}$ exposure to HBCD followed by $48 \mathrm{~h}$ in HBCD-free media, (C) $1 \mathrm{~h}$ exposure to HBCD followed by 6 days in HBCD-free media. 